\title{
The Effect of Local Labor Demand Conditions on the Labor Supply Outcomes of Older Americans
}

Nicole Maestas, Kathleen J. Mullen, David Powell

RAND Labor \& Population

WR-1019

September 2013

This paper series made possible by the NIA funded RAND Center for the Study of Aging (P30AG012815) and the NICHD funded RAND Population Research Center (R24HD050906).

RAND working papers are intended to share researchers' latest findings and to solicit informal peer review. They have been approved for circulation by RAND Labor and Population but have not been formally edited or peer reviewed. Unless otherwise indicated, working papers can be quoted and cited without permission of the author, provided the source is clearly referred to as a working paper. RAND's publications do not necessarily

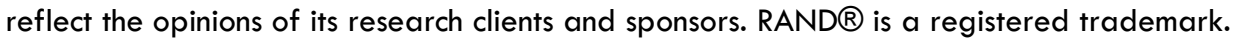


The Effect of Local Labor Demand Conditions on the Labor Supply Outcomes of Older Americans ${ }^{1}$

\author{
Nicole Maestas ${ }^{2}$ \\ Kathleen J. Mullen \\ David Powell \\ RAND
}

September 2013

\begin{abstract}
A vast literature in labor economics has studied the relationship between local labor demand shifts and the outcomes of the working age population. This literature has ignored the impacts that these shocks have on older individuals, though there are reasons to believe that the effects are not uniform by age. Using data from the Census and the Health and Retirement Study, we measure the effects of local labor demand conditions on a host of outcomes for older individuals including employment, retirement, Social Security claiming, wages, and job characteristics. We find that local labor demand conditions do affect the labor and retirement behavior of the older segment of the population, including Social Security claiming decisions. We also find evidence that older individuals are especially responsive to local labor demand shifts in the service industry, which we show has observably different job characteristics that may be especially attractive to older workers. Similarly, we find evidence that labor demand shocks not only increase the wages of older workers but also make the jobs more attractive on non-pecuniary dimensions.
\end{abstract}

\footnotetext{
${ }^{1}$ We thank the Sloan Foundation for funding this research.

${ }^{2}$ Nicole_Maestas@rand.org
} 


\section{Introduction}

Local labor demand shocks have been shown to affect employment and wages for the working age population. Relatively little research has looked at how changes in labor demand affect older individuals, though this is a group that is potentially very responsive to changes in compensation, the availability of jobs, and the availability of specific types of jobs. We explore the consequences of labor demand conditions on older individuals in the United States. Because we observe labor markets that change due to both shifts in labor supply and labor demand, we use an approach that isolates changes in local labor demand. While this approach is commonly used in the labor economics literature, it has - to our knowledge - never been applied to the older segment of the population. Instead, researchers frequently exclude older individuals from their analysis when analyzing the importance of local labor demand conditions on labor outcomes. We find evidence that older individuals do respond to local labor demand conditions, but we show that this response appears to be especially reliant on the importance of non-pecuniary job characteristics.

We study how changes in labor demand impact the work and retirement outcomes of older Americans by connecting the study of employment and retirement transitions to the local labor markets in which these transitions play out. While the retirement literature has focused mostly on the supply side of the labor market, the literatures on labor demand and local labor markets have focused almost exclusively on younger workers. This paper brings together these strands of the economics literature to investigate how shifts in labor demand across industries and local labor markets affect the labor supply outcomes of older workers. Only a handful of studies have touched on the demand side of the labor market for older workers, with intriguing results. In a study of the age structure of hires into different occupations, Hirsch et al. (2000) conclude that employment opportunities for older workers are restricted. Older workers are least likely to be hired into occupations requiring substantial computer use or where the return to job tenure is high, and most likely to be hired into lower-wage occupations. Lahey (2008) finds compelling evidence of statistical discrimination in hiring of older female workers based on an audit study in two local labor markets. Blau and Shvydko (2011) develop a model of the labor market in which technological rigidity affects the age structure of a firm's work force in equilibrium. They hypothesize that older workers are attracted to firms using flexible production technologies that allow for variation in hours of work per worker, and not to firms using more rigid, team production technologies that impose a constraint on the minimum number of hours that must be worked. 
Two recent studies look at the near-term effects of the Great Recession on retirement behavior. Coile and Levine (2011) use the Current Population Survey (CPS) to analyze the effect of business cycle fluctuations on retirement (defined as labor force withdrawal) by relating variation in state unemployment rates (for all industries combined) over a 30-year period to labor force withdrawal rates. They conclude that recessions significantly accelerate retirements as older workers are laid off from career employment. In contrast, Gustman, Steinmeier, and Tabatabai (2011) conclude from a crosscohort analysis of HRS data that adverse effects of the Great Recession on retirement have been relatively modest. They find that flows out of full-time work or partial retirement did not accelerate as unemployment rose.

Banerjee and Blau (2013) document a rise in employment rates at old ages and a decline at younger ages since the 1990's and conclude that the trends can partially be explained by changes in demographics but that much of the divergence remains unexplained. If labor force participation continues to rise, it could significantly offset the detrimental effects of population aging on fiscal budgets and economic growth (Maestas and Zissimopoulos, 2010). On the labor supply side, today's older workers appear poised to work more than earlier cohorts; when asked about their retirement plans, Baby Boomers predict a higher likelihood of working at older ages than did earlier birth cohorts (Maestas 2007). In our analysis, we consider the possibility that labor demand shocks may have differential effects by age. Furthermore, we are motivated by evidence that older workers often want jobs that are different from their career jobs-they want to gradually reduce their hours by working part-time, they want greater flexibility around when and where they work, and they often want less responsibility (Roper ASW 2002). Some research has suggested that non-pecuniary factors are especially important for the continued labor supply of older workers (Haider and Loughran, 2001).

In Figure 1, we document the relative rise in employment for older individuals in the United States using data from the Census and American Community Survey. We normalize the employment rate (number of individuals working divided by total number of individuals in the age group) to 100 in the 1980 Census and graph the employment rate by age over time. ${ }^{3}$ We see a large increase over time in employment for both the 55-64 and 65-74 age groups. We see declines in employment for the other age groups since 1990. The driving forces behind this relative growth of employment for the older segment of the population have not been entirely explained. We provide evidence that this relative growth can be explained by differential responses to the growth of specific industries. The growth of

\footnotetext{
${ }^{3}$ We focus on the employment rate so changes in cohort size should not explain this growth.
} 
service occupations in the United States has been well-documented and researched (Autor and Dorn, 2009; Lee and Wolpin, 2006). However, there is little work on the differential impact that this growth may have on older workers.

Figure 2 shows employment growth in the service industries for all age groups. We calculate employment in the service industries divided by the total population for each age group. This service industry-specific employment rate is normalized to 100 in 1980 . While the $65-75$ experienced $40 \%$ growth in their employment rate between 1980 and 2010,30\% of this growth can be attributed solely to service industries, which we define as Business and Repair Services, Personal Services, Entertainment and Recreation Services, and Professional Services. This rapid growth for the older age group outpaces the growth for all other age groups. Figure 3 shows growth in non-service industries. Here, we see the additional $10 \%$ in growth for the $65-74$ age group. While the overall employment growth of older individuals (Figure 1) has been documented in the literature, we have not seen research detailing that this growth can be overwhelming attributed to growth in service industry employment. This relative effect motivates us to test for differential effects by industry and study whether older workers appear to be more responsive to growth in jobs with specific characteristics.

Our primary empirical strategy is to study the impact of local labor demand shocks on older worker labor outcomes. Due to concerns of simultaneity bias, we use an exogenous shock to labor demand introduced in Bartik (1991) which interacts national changes in industry employment with cross-sectional differences in industry composition. This instrument, which we will refer to as the "Bartik instrument," has been frequently applied as an exogenous source of labor demand changes in the labor economics literature, including Blanchard and Katz (1992), Bound and Holzer (2000), Autor and Duggan (2003), Luttmer (2005), Wozniak (2010), Notowidigo (2013), and Bartik (2013). This literature has looked at the impact of these labor demand shocks on a variety of outcomes for recent college graduates and the working age population. The literature has largely ignored the effects of labor demand on the labor outcomes of the older segment of the population, frequently explicitly excluding older individuals from the analysis. Labor demand shocks, however, may not have uniform effects. While the literature has found that local labor demand shocks do impact employment rates, it is difficult to infer whether such shocks could influence more permanent labor supply decisions such as retirement.

We test the effects of these labor demand shocks on the labor outcomes of older workers. First, we look at geographic-level outcomes, studying the effects of local labor demand shocks on local 
employment growth. We perform this analysis by age and test to what extent older workers share in area employment growth. We find evidence that older workers benefit from growth resulting from local demand shocks.

Second, we study whether growth in specific industries promotes differential employment growth by age. We hypothesize that certain job characteristics valued by older workers are more prevalent in specific industries. We show that the disproportionate growth experienced by older individuals in response to local labor demand shocks can be entirely attributed to service industryspecific shocks.

Third, we use individual-level panel data to estimate the effects of local labor demand conditions on a variety of employment outcomes. We find that labor demand shifts increase the probability that individuals work and decrease the probability of retirement. Fourth, because local labor demand can induce people to change their retirement patterns, we test whether Social Security claiming behavior is also affected. If an individual is encouraged to work longer due to a growing local labor market, then that individual may also defer claiming Social Security benefits. We find significant effects on this dimension for individuals ages 62-64. Finally, we estimate the effect of labor demand shocks on wages and non-wage job characteristics. We find evidence that wages respond but also that the jobs improve on non-pecuniary dimensions as well.

In the next section, we describe our data. Section 3 describes our empirical strategy. We discuss our results in Section 4 and conclude in Section 5.

\section{Data}

We use multiple data sets in our analysis. First, we use the 1980, 1990, and $20005 \%$ Census Samples. We add the 2009-2011 American Community Survey (ACS) to these data sets. The Census and ACS provide information about labor supply, demographics, and metropolitan area (for areas that are not masked). We construct MSA-level data using these data. We combine the 2009-2011 ACS data sets, averaging all MSA statistics across years. In our analysis, we treat these observations as one year (2010). The ACS is relatively small compared to the Census samples ( 14 million observations in the 2000 Census, 3 million in the 2010 ACS) and averaging should reduce the noise of the 2010 MSA-level estimates. Across all years, we can identify 287 different MSAs. ${ }^{4}$ We use the employment status variable to

\footnotetext{
${ }^{4}$ We drop 3 MSAs which have evidence of mismeasured labor demand shocks. See Notowidigo (2013) for details.
} 
identify workers and construct hourly wages by dividing annual wage and salary income by the product of weeks worked and usual hours worked per week. ${ }^{5}$ The Bartik instrument for the Census sample is constructed using the Census employment data. We create 14 industry categories. These industry categories and summary statistics are presented in Table 1.

We also use the nationally representative Health and Retirement Study (HRS). The HRS has several advantages for our analysis. First, it is longitudinal so we can study the effect of labor demand shocks on employment and retirement transitions. The HRS surveys individuals ages 51 and above, and we limit our sample to ages 55-74 to focus on an age group that is typically not considered "working age" and commonly excluded from empirical analysis. Second, the HRS includes self-reported retirement information which helps us distinguish individuals that are unemployed from those that consider themselves retired. Third, the HRS has several measures of non-pecuniary job characteristics, which like wages, may be an important margin of response to local labor demand shocks. Finally, we use a geocoded version of the HRS which includes detailed geographic information, allowing us to link the HRS with local area economic data. The geocoded data are necessary for our empirical strategy and are currently available up to 2008. Our HRS analysis, consequently, uses data from 1992 to 2008 . We observe 20,240 individuals in our data.

We link the HRS with the Quarterly Census of Employment and Wages (QCEW) for the period 1992-2008. ${ }^{6}$ The QCEW data contain a quarterly count of employment and wages for workers covered under state unemployment insurance (UI) laws and for federal workers covered by the Unemployment Compensation for Federal Employees (UCFE) program. The data are reported by employers and cover 98 percent of U.S. jobs. The data are available by industry. Industries are coded using the North American Industry Classification System (NAICS); although NAICS only replaced the older SIC system in 1997, the 1991-1996 files have been converted by the QCEW to the NAICS system. Our analysis focuses at the level of 2-digit NAICS industries, referred to as sectors.

Our primary definition of a local labor market for the HRS analysis will be a commuting zone (CZ). The concept of commuting zones was introduced by Tolbert and Sizer (1996), who used countylevel commuting data from the 1990 Census to group counties into 741 clusters based on the strength of commuting ties. Most recently, Autor et al. (2013) use the CZ approach to study employment and wage

\footnotetext{
${ }^{5}$ The ACS only provides weeks worked in intervals. We predict number of weeks for each interval using the earlier Census data and impute the average number of weeks for the ACS sample.

${ }^{6}$ In our Census analysis, we use the Census both to generate our outcomes and the Bartik instrument. We do this because the Census has its own industry classification system.
} 
polarization in local labor markets. Unlike Metropolitan Statistical Areas (MSAs), CZs cover the entire U.S. and unlike counties, they do not constrain local labor markets to fall within state boundaries.

\section{Empirical Strategy}

The level of employed labor in an MSA or CZ is a function of both labor demand and labor supply. We only observe the equilibrium and using observed changes in labor confounds whether the results are driven by supply or demand. Instead, we use labor demand shocks as our identifying source of variation. We employ the Bartik instrument to act as our exogenous change in local labor demand. The Bartik instrument is constructed by using national changes in employment by industry interacted with a geographic area's initial baseline industry composition. The first step is to predict next period's employment in the geographic area using the following formula:

$\hat{L}_{j t}=\sum_{k}\left[\left(\frac{\text { National Employmentin Industry } k \text { at time } t}{\text { National Employment in Industry } k \text { at time } t-1}\right) \times(\right.$ Area $j$ Employmentin Industry $k$ at time $\left.t-1)\right]$ where $j$ indexes geographic area and $t$ indexes time. Predicted employment in the next period relies only on initial industry composition and national growth rates. An area's own growth is not used in this formula. The Bartik Instrument, then, is simply the predicted employment growth rate:

$$
\text { Bartik Instrument }_{j t}=\frac{\hat{L}_{j t}-L_{j, t-1}}{L_{j, t-1}}
$$

Equivalently, we can write this equation as

$$
\text { Bartik Instrument }_{j t}=\frac{\sum_{k}\left[L_{j k, t-1}\left(\frac{L_{k t}}{L_{k, t-1}}-1\right)\right\rfloor}{\sum_{k} L_{j k, t-1}} .
$$

This equation illustrates how the national industry-specific employment growth $\left(\frac{L_{k t}}{L_{k, t-1}}\right)$ interacts with the geographic-level initial distribution for variation. The Bartik instrument does not use industryspecific variation in growth at the geographic-level because this source of variation is potentially problematic and driven by labor supply shocks. Note that the total change in employment in geographic 
area $j$ can be divided into an "exogenous component" (Bartik Instrument) and deviations from this predicted change in the employment rate:

$$
\frac{L_{j t}-L_{j, t-1}}{L_{j t}}=\left(\text { Bartik Instrument }{ }_{j t}\right)+\frac{\overbrace{\sum_{k} L_{j k t}}^{\text {Actual }}-\overbrace{\sum_{k} L_{j k, t-1}\left(\frac{L_{k t}}{L_{k, t-1}}\right)}^{\text {Predicted }}}{\sum_{k} L_{j k, t-1}}
$$

where use of $\sum_{k} L_{j k t}$ would potentially bias our analysis. Consequently, we only use the exogenous source of variation. Note that we are studying growth rates and all specifications will include year fixed effects. Our analysis is similar to a differences-in-differences framework where we study growth in employment rates in an area relative to employment rate growth nationally. Our empirical strategy is to study changes in outcomes of geographic areas or people that experience larger local labor demand shocks relative to the national average and only due to initial industry composition.

In some of our analysis, we will test whether specific industries have differential effects on the older segment of the population. We create "industry-specific Bartik instruments":

$$
\text { Industry } k \text { Bartik Instrument }{ }_{j t}=\frac{L_{j k, t-1}\left(\frac{L_{k t}}{L_{k, t-1}}-1\right)}{\sum_{k} L_{j k, t-1}}
$$

where the denominator is the same as in the aggregate Bartik instrument. We do this to make the coefficients on the corresponding employment variables comparable in terms of magnitude. Otherwise, small industries in an area with very fast growth would not appear to have any effect on employment even if they have a large effect given their size within the area. Instead, we measure growth by the increase in employment relative to total employment in the area.

In our analysis of the Census data, our time periods are 10 years apart. Table 2 includes the national growth in industry-specific employment over time. We present growth for the entire sample and for our MSA-only sample. The latter will be used in our analysis. The Bartik instrument requires differential growth by industry. Uniform growth would imply that all MSAs would be predicted to grow at the same rate. Table 2 illustrates that there is significant variation across industries. 
Table 3 presents employment shares by industry. Manufacturing and Retail Trade are the largest industries, even after a large decline in Manufacturing throughout our sample. Table 4 provides the mean predicted employment growth in our MSA sample. These numbers show the overall and annual exogenous labor demand component of employment growth.

\subsection{Census}

Our initial specifications are equivalent to reduced form regressions where we examine the relationship between our outcomes and the Bartik instrument. In the Census, we estimate the following reduced form specification to relate changes in predicted local employment to age-specific actual changes in employment, where $a$ denotes 10 -year age categories. We compare the coefficients across age groups to observe how a common labor demand shock may differentially affect the labor outcomes of different age groups.

$$
\frac{L_{a j t}-L_{a j, t-1}}{L_{a j, t-1}}=\gamma_{a t}^{L}+\beta_{a}^{L}\left[\frac{\hat{L}_{j t}-L_{j, t-1}}{L_{j, t-1}}\right]+\varepsilon_{a j t}^{L}
$$

We estimate this equation separately for 10 -year age categories. We also examine wage growth, estimating the following specification:

$$
\frac{w_{a j t}-w_{a j, t-1}}{w_{a j, t-1}}=\gamma_{a t}^{w}+\beta_{a}^{w}\left[\frac{\hat{L}_{j t}-L_{j, t-1}}{L_{j, t-1}}\right]+\varepsilon_{a j t}^{w}
$$

where $w_{a j t}$ represents the average wage for individuals of age $a$ in MSA $j$ at time $t$. We also present instrumental variable (IV) estimates of the following specification:

$$
\frac{L_{a j t}-L_{a j, t-1}}{L_{a j, t-1}}=\gamma_{a t}^{I V}+\beta_{a}^{I V}\left[\frac{L_{j t}-L_{j, t-1}}{L_{j, t-1}}\right]+\varepsilon_{a j t}^{I V}
$$

We use the Bartik instrument to exogenously shock the MSA's growth rate in employment with a shock to the change in labor demand. The advantage of this specification is that we can relate the total MSA employment growth to age-specific changes. We estimate this equation for 5 year age groups and present the results graphically. 
We also look at the effects of industry-specific growth rates, estimating equation (5) with an industry-specific growth rate variable and a growth rate for all other industries. While equation (5) constrains all employment growth to have the same effect on the age-specific employment growth outcome, including industry-specific terms allows the effects to vary by industry.

All standard errors in our analysis of the Census data are adjusted for clustering at the MSAlevel. All regressions are weighted by total MSA employment in period $t-1$.

\subsection{HRS}

Our primary analysis in the HRS will estimate work and retirement outcomes. We estimate specifications of the form:

$$
P\left(\text { Work }_{\mathrm{ijt}}=1 \mid \operatorname{Work}_{\mathrm{ij}, \mathrm{t}-1}=1\right)=\Phi\left(\gamma_{t}+X_{i t}^{\prime} \delta+\beta\left[\frac{\hat{L}_{j t}-L_{j, t-1}}{L_{j, t-1}}\right]\right)
$$

We estimate the probability that an individual works in period $t$, selecting the sample based on people that were working in period $t-1$. The variable of interest is the Bartik instrument. We assign an individual the predicted labor demand shock that they would have experienced had they remained in the same $C Z$. While migration rates are low in our sample, we fix the $C Z$ when assigning the Bartik instrument to avoid concerns of endogenous migration. We include age, year, and sex fixed effects in all regressions. We estimate the above probability, but we also look at the probability of work for the sample of people that were not working in the prior period. We perform the same analysis for retirement using the HRS's self-reported retirement measure. We report the marginal effect of a small predicted labor demand increase. Using the estimated coefficients, we calculate the probability of the outcome when there is a predicted increase in labor demand of 0.01 :

$$
\Phi\left(\hat{\gamma}_{t}+X_{i t}^{\prime} \hat{\delta}+\hat{\beta}\left[\frac{\hat{L}_{j t}-L_{j, t-1}}{L_{j, t-1}}\right]+0.01\right)-\Phi\left(\hat{\gamma}_{t}+X_{i t}^{\prime} \hat{\delta}+\hat{\beta}\left[\frac{\hat{L}_{j t}-L_{j, t-1}}{L_{j, t-1}}\right]\right)
$$

We calculate this for each individual in the sample and report the average. Standard errors are generated using a clustered (by CZ) bootstrap. We use the HRS sampling weights in our analyses. 


\section{Results}

\subsection{Census}

The Bartik instrument has the advantage that it reduces simultaneity concerns that labor supply shocks are driving changes in the employment rate. However, this measure is not useful if it does not predict actual MSA-level changes in employment. We plot the first-stage relationship between the Bartik instrument and the actual change in the employment rate in Figure 3 . We do this by first demeaning both the instrument and the employment growth variables in each year. This normalizes the variables across years. Figure 3 shows that there is a predictive relationship. This relationship is statistically significant with an F-statistic of 31.87. We find a magnitude of 2.4, implying that when employment growth is predicted to grow by 1 percentage point, employment actually grows - on average - by 2.4 percentage points. This relationship suggests multiplier effects - as some industries grow for exogenous reasons, the additional employment and earnings in those industries lead to more general growth in the area.

Table 5 presents the estimates of the effects of predicted labor demand changes on employment and wages by age group. We find statistically significant effects for both outcomes at all ages. The impact on employment growth is largest for the upper part of the age distribution. Wage growth is most impacted for ages $25-34$. Note that we find relatively large employment growth effects given the estimated wage growth. The employment growth estimates include both changes in employment for people living in an MSA and migration into the MSA so we should expect the implied MSA labor elasticity to be large.

It is more straightforward to interpret the results using IV and estimating equation (5). This specification estimates the age-specific effect of employment growth. We estimate the equation for 5 year age groups $(25-29,30-34, \ldots, 70-74)$. We present the results graphically in Figure 4 where the coefficient is matched to the youngest age in the age group (eg., the coefficient for age $=25$ refers to the 25-29 age group). The estimates state that employment growth of 0.01 in an MSA leads to employment growth of 25-29 year olds of over 0.011. This effect is centered around 1 for all ages, but reaches its peak value for the 60-64 age group. At no point can we reject an effect of 1, but we can reject that all the coefficients are equal at a $5 \%$ significance level. We can also reject that the effect is equal for the 55-59 and the 60-64 age groups (5\% significance level). 
Older individual employment appears to be responsive to local labor demand shifts. However, we are also interested in whether older individuals respond simply to job growth or whether they respond differentially to growth in specific types of jobs. Given the growth in the service industries during our time period, we test whether employment for the older segment of the population is especially responsive to growth in the service industries, which we define as the following industries: Business and Repair Services, Personal Services, Entertainment and Recreation Services, and Professional Services. Our primary motivation for this hypothesis is that service jobs tend to have characteristics older individuals should value. While we will analyze the job characteristics included in the HRS data in the next section, we use these data here to show observable differences between jobs in the service industry and jobs in other industries.

Table 6 lists the variables in the HRS, divided into three categories: Job Requirements, Employer Policy, and Psychosocial Responses. These variables include characteristics which are likely important to older workers. We analyze the difference between service industries and other industries in Table 7. We find that service industries are less likely to require lots of physical effort, less likely to require lifting heavy loads, and less likely to require stooping, kneeling, or crouching. We also find that service industries are more likely to allow employees to reduce their hours. Using the psychosocial responses, we find that individuals working in service industries are more likely to report enjoying going to work. On the other hand, the jobs are more stressful, require more concentration, and the employers are reported by the respondents to be less likely to accommodate older employees by transitioning them to less demanding jobs. Overall, however, there are significant differences in how flexible and physically demanding the jobs are, which have been argued to be especially important to older workers (Roper ASW, 2002; Banerjee and Blau, 2013; Haider and Loughran, 2001; Pitt-Catsouphes and Smyer, 2005).

We perform instrumental variable regressions of age-specific employment growth on nonservice employment growth and service industry employment growth. We use comparable Bartik instruments. The previous analysis assumed that growth in every industry had the same effect. We now relax this assumption and allow the service industry to have its own effect. Figure 5 graphs both sets of coefficients by age group. Here, we see that older individuals do not appear to benefit at all from non-service labor demand shocks as we find a negative effect which is statistically insignificant from 0 , but we can reject an effect of 1 . Instead, Figure 5 provides evidence that older workers benefit disproportionately from service industry labor demand shocks. We can reject equality of all the coefficients on the service industry variables. Furthermore, each of the coefficients for $60+(60-64,65-$ 
$69,70-75)$ is statistically different from the 55-59 coefficient. We can also reject that the 65-69 and 7074 coefficients for the non-service industry are equal to 1 .

We present the same estimates by 10 year age groups in Table 8. For each age group, we show three regressions. The first is equivalent to the coefficients seen in Figure 4 - the age-specific impact of MSA employment growth. The second are equivalent to the coefficients found in Figure $5-$ the regressions include a non-service employment growth variable and a service industry employment growth variable. The third set replaces "service" with "retail trade." We do this to show that we get different results with a different industry and because retail trade looks like a potentially important industry for older workers in the summary statistics (Table 1). Ages 35-44 appear to benefit disproportionately from retail employment growth, but older individuals do not derive much employment benefit. Again, we find that the oldest age group receives a large and statistically significant effect from growth in the service industries. Furthermore, when we include service industry growth, the effect of non-service industry growth is actually negative and statistically different from 1.

These results suggest that recent employment growth for older workers relative to younger workers is driven by the growth in the service industry. Figure 2 provided time series evidence about the importance of service industry growth, but it is difficult to know whether these trends are driven by labor supply or labor demand changes. The analysis in this section shows that areas with particularly fast employment growth in the service industry due to local labor demand shocks experienced disproportionate increases in the employment rate of older individuals. This evidence suggests that the relative gains of older individuals in employment were demand-driven and driven by the relative changes in demand across industries. Furthermore, we show that a possible reason that growth in the service industry would disproportionately affect the labor outcomes of older individuals is because the service industry provides jobs with non-pecuniary characteristics that are especially attractive to this segment of the population.

\subsection{HRS}

Using the Census and ACS, we found evidence that older workers are responsive to shifts in local labor demand. And, we showed that they are more responsive to these shifts for the service industry which tends to include jobs that are more flexible and less physically demanding. We use the HRS to test these results further. 
The HRS has the benefit that we can observe individuals in multiple time periods. In the Census, we only observe people in their current MSA. In the HRS, however, we observe migration. We can isolate the effect of a predicted change in local labor demand conditions on people in that geographic area from individuals migrating into the area. Table 9 presents statistics for the Bartik instrument in the HRS. We observe some variation in predicted local labor conditions across commuting zones over time.

Table 10 presents the primary results from the HRS. We find that predicted employment growth of 0.01 increases the probability of a worker continuing to work by 0.007 , which is statistically significant from 0 at the $5 \%$ level. We estimate that individuals not working in the initial period are more likely to begin working. An increase in predicted employment growth of 0.01 also causes an increase in the probability of transitioning into work by 0.006 . Note that this is an especially large effect relative to the baseline. Only $9 \%$ of non-workers return to work 2 years later.

We find similar effects on retirement. Individuals that are not retired are less likely to retire when local labor conditions improve exogenously. We find no evidence that local labor demand shocks affect the probability of retired individuals reporting that they are not retired in the next period.

We look at these results by different categories and find that women seem especially responsive on the work dimension. While not statistically significant, we also find evidence that the results are primarily driven by the high education group, which we define as those with at least some college education.

We also look at whether service industry shocks have larger effects on the probability of working. Table 11 separates the components of the Bartik instrument as before into a service industry Bartik and a non-service industry Bartik. For individuals working in period $t-1$, we find that the employment effect is dominated by the service industry. We find little differential effect for individuals not working in the initial period. Overall, the evidence in Table 11 is consistent with our findings in the Census and ACS.

We are also interested in the driving forces behind the increased employment found in Table 10. An obvious mechanism to encourage people to remain in or join the labor force is increasing the wage. Table 12 looks at the effect of labor demand shocks on wages and labor earnings. In Column 1, we present estimates from an OLS regression of the log of the wage on the Bartik instrument for individuals that were previously working. We find a large and statistically significant effect suggesting that an increase in predicted labor demand of 0.01 is associated with 0.12 percent wage growth. In Column 2, 
we control for the log of the wage in the previous period. The estimate decreases but is still significantly different from 0. In Column 3, we look at individuals not working in the previous period and also find statistically significant effects on wages. Though not shown, we also re-estimated these three columns using median regression due to concerns that wage outliers were driving the results. The results are equivalent using median regression.

Columns 4-6 look at total labor earnings. We use non-linear least squares and estimate the following specification:

Labor Earnings $_{\mathrm{ijt}}=\exp \left(\gamma_{t}^{l}+X_{i t}^{\prime} \delta^{l}+\beta^{l}\left[\frac{\hat{L}_{j t}-L_{j, t-1}}{L_{j, t-1}}\right]\right) \eta_{i j t}^{l}$

We use non-linear least squares because the distribution of labor earnings is skewed due to a small set of individuals with very high earnings. However, a log-linear specification would also be inappropriate since many individuals have no labor earnings. We follow Silva and Tenreyro (2006) and implement a Poisson regression. We report the change in labor earnings due to an increase in predicted labor demand by 0.01 . Standard errors are generated using a clustered (by CZ) bootstrap. Columns 4-6 in Table 12 find that shocks to local labor demand lead to large increases in labor earnings for those that are working. When conditioning on initial labor earnings, we find that this local labor demand shock is worth $\$ 2530$ in additional labor earnings. We find more modest effects for individuals not working in the initial period, though relative to the mean labor earnings for this group, the effect is large.

Given that these labor demand shocks are affecting total labor earnings, it is plausible that individuals would substitute better local labor conditions for Social Security. By delaying claiming, individuals can increase their future payments. We estimate this relationship by age in Table 13 . We find significant relationships for ages 62-64 and little relationship after that - with the exception of a marginally significant effect at age 69. These results are especially interesting because they show that Social Security claiming depends on local labor demand conditions. If individuals' potential labor earnings increase, they are more likely to delay claiming and increase their monthly benefits. The magnitudes in Table 13 are large. We estimate that a 1 percentage point increase in predicted labor demand growth leads to a reduction in the probability of claiming Social Security by 0.067 for individuals age 62. 
Table 12 provided evidence that wages increase due to local labor demand shifts. However, wages are not the only potential mechanism to encourage workers to remain in or join the labor force. Our analysis of the Census and ACS data revealed that older individuals are more responsive to shocks in an industry with specific characteristics. The HRS data allow us to analyze the relationship between local labor demand shocks and these characteristics more explicitly. We use the job characteristics in the HRS to study whether on-the-job amenities also respond to labor demand shocks. These job characteristics are asked of a subsample of the HRS. The characteristics that we study were listed in Table 6.

We estimate equations of the form:

$$
P\left(\text { Heavy }_{\mathrm{ijt}}=1\right)=\Phi\left(\gamma_{t}^{j}+X_{i t}^{\prime} \delta^{j}+\beta^{j}\left[\frac{\hat{L}_{j t}-L_{j, t-1}}{L_{j, t-1}}\right]+\lambda^{j} \operatorname{Heavy}_{\mathrm{ij}, \mathrm{t}-1}\right)
$$

Note that we control for previous values of the variable when we look at individuals working in the previous period. When we look at people not working in the initial period, this variable is not available. Table 14 presents the results. Table 14 shows that several job characteristics respond to labor demand shifts. There is evidence that older workers are not entirely interested in wages but also respond to changes in on-the-job amenities. We find significant evidence that labor demand shocks reduce the probability that an older worker has a job requiring physical effort, lifting heavy loads, and stooping/crouching/kneeling. These are the same characteristics that appeared to be important in our Census/ACS analysis. We find marginally significant evidence that flexibility in hours also responds to these labor demand shocks.

Finally, we return to the basic question of the impact of labor demand shocks on labor outcomes. Instead of using the Bartik instrument, we use the interaction of national demand shocks and the differential effect that these should have on individuals based on their initial industry. This analysis studies whether individuals in declining industries experience different labor outcomes than other workers. We are especially interested in the potential impact of significant industry declines on retirement. We create an indicator for "Poor Growth" which is equal to 1 for industries in the bottom $10 \%$ of growth in that year. We control for the same variables as before but also condition on industry fixed effects. We then report the marginal effects for this indicator variable. We look at a host of outcomes: full-time work, full-time or part-time work, full-time or part-time retirement, full-time 
retirement, changing industry, and log(wage). Table 15 shows supportive evidence that bad growth shocks decrease the probability of working and increase the probability of retirement. Retirement is especially impacted for women and the low education group.

\section{Conclusion}

This paper provides evidence that older Americans are responsive to local labor demand conditions on a host of outcomes. When local labor demand conditions improve, they are more likely to work, less likely to retire, and more likely to delay Social Security claiming. They also earn higher wages. We also find evidence that they respond differentially to specific types of job characteristics. We show this in multiple ways. First, in the Census and ACS, we show that older individuals are especially responsive to local shocks to the service industry, an industry which tends to offer more flexible and less physically demanding jobs. Second, using longitudinal data, we find similar evidence that service-specific demand shocks increase the probability of working for older workers. Finally, local labor demand shocks affect non-pecuniary job characteristics, suggesting that older workers value more than just wages. They appear to value jobs that are flexible and less physically demanding. While the literature has frequently studied the impacts of local labor demand conditions, it has ignored the older segment of the population. These are some of the first results concerning their effects on older individuals and provide some of the first evidence about the interaction of local labor conditions and retirement decisions. 


\section{References}

Autor, David and David Dorn (2009). "The growth of low skill service jobs and the polarization of the US labor market." National Bureau of Economic Research.

Autor, David H. and David Dorn and Gordon H. Hanson (2013). "Untangling trade and technology: Evidence from local labor markets." National Bureau of Economic Research.

Autor, David and Mark Duggan (2003). "The rise in the disability rolls and the decline in unemployment." The Quarterly Journal of Economics, 118(1), 157-206.

Banerjee, Sudipto and David Blau (2013). "Employment Trends by Age in the United States: Why are Older Workers Different?" Michigan Retirement Research Center Working Paper.

Bartik, Timothy J. (1991). "Who Benefits from State and Local Economic Development Policies?" W.E. Upjohn Institute for Employment Research: Kalamazoo, MI.

Bartik, T. J. (2013). "How Effects of Local Labor Demand Shocks Vary with Local Labor Market Conditions." Working paper.

Blanchard, Olivier Jean and Lawrence Katz (1992). "Regional evolutions." Brookings Papers on Economic Activity 1992.1: 1-75.

Blau, David and Tetyana Shvydko (2011). "Labor Market Rigidities and the Employment Behavior of Older Workers." Industrial \& Labor Relations Review, 64:464.

Bound, John, and Harry J. Holzer (2000). "Demand shifts, population adjustments, and labor market outcomes during the 1980s." Journal of Labor Economics 18.1: 20-54.

Coile, Courtney C. and Phillip B. Levine (2011). "The Market Crash and Mass Layoffs: How the Current Economic Crisis May Affect Retirement." The BE Journal of Economic Analysis \& Policy 11(1): 22.

Gustman, Alan L., Thomas L. Steinmeier and Nahid Tabatabai (2011). "How Did the Recession of 20072009 Affect the Wealth and Retirement of the Near Retirement Age Population in the Health and Retirement Study?" Michigan Retirement Research Center, Working Paper UM11-08.

Haider, Steven and David S. Loughran (2001). "Elderly Labor Supply: Work or Play?" RAND Working Paper.

Hirsch, Barry T., David A. Macpherson, and Melissa A. Hardy (2000). "Occupational Age Structure and Access for Older Workers," Industrial and Labor Relations Review, 53, 401-418.

Lahey, Joanna (2008). "Age, Women, and Hiring: An Experimental Study," Journal of Human Resources, $43,30-56$.

Lee, Donghoon and Kenneth I. Wolpin (2006). "Intersectoral labor mobility and the growth of the service sector." Econometrica, 74(1), 1-46.

Luttmer, Erzo F. (2005). "Neighbors as negatives: Relative earnings and well-being." The Quarterly Journal of Economics, 120(3), 963-1002.

Maestas, Nicole (2010). "Back to Work: Expectations and Realizations of Work after Retirement," Journal of Human Resources, 45(3).

Maestas, Nicole and Julie Zissimopoulos (2010). "How Longer Work Lives Ease the Crunch of Population Aging," Journal of Economic Perspectives, 24(1):139-160.

Notowidigdo, Matthew J. (2013). "The Incidence of Local Labor Demand Shocks." Working paper. 
Pitt-Catsouphes, Marcie and Michael A. Smyer (2005). "Older Workers: What Keeps Them Working?" Issue Brief for The Center on Aging \& Work at Boston College.

Roper ASW (2002): "Staying Ahead of the Curve: The AARP Work and Career Study," Washington, D.C.: AARP.

Silva, JMC Santos and Silvana Tenreyro (2006). "The log of gravity." The Review of Economics and Statistics. 88.4: 641-658.

Tolbert, Charles M. and Molly Sizer (1996). "U.S. Commuting Zones and Labor Market Areas: A 1990 Update." Economic Research Service Staff Paper No. 9614.

Wozniak, A. (2010). "Are college graduates more responsive to distant labor market opportunities?" Journal of Human Resources, 45(4), 944-970. 


\section{Figures}

Figure 1: Employment Growth by Age, 1980-2010

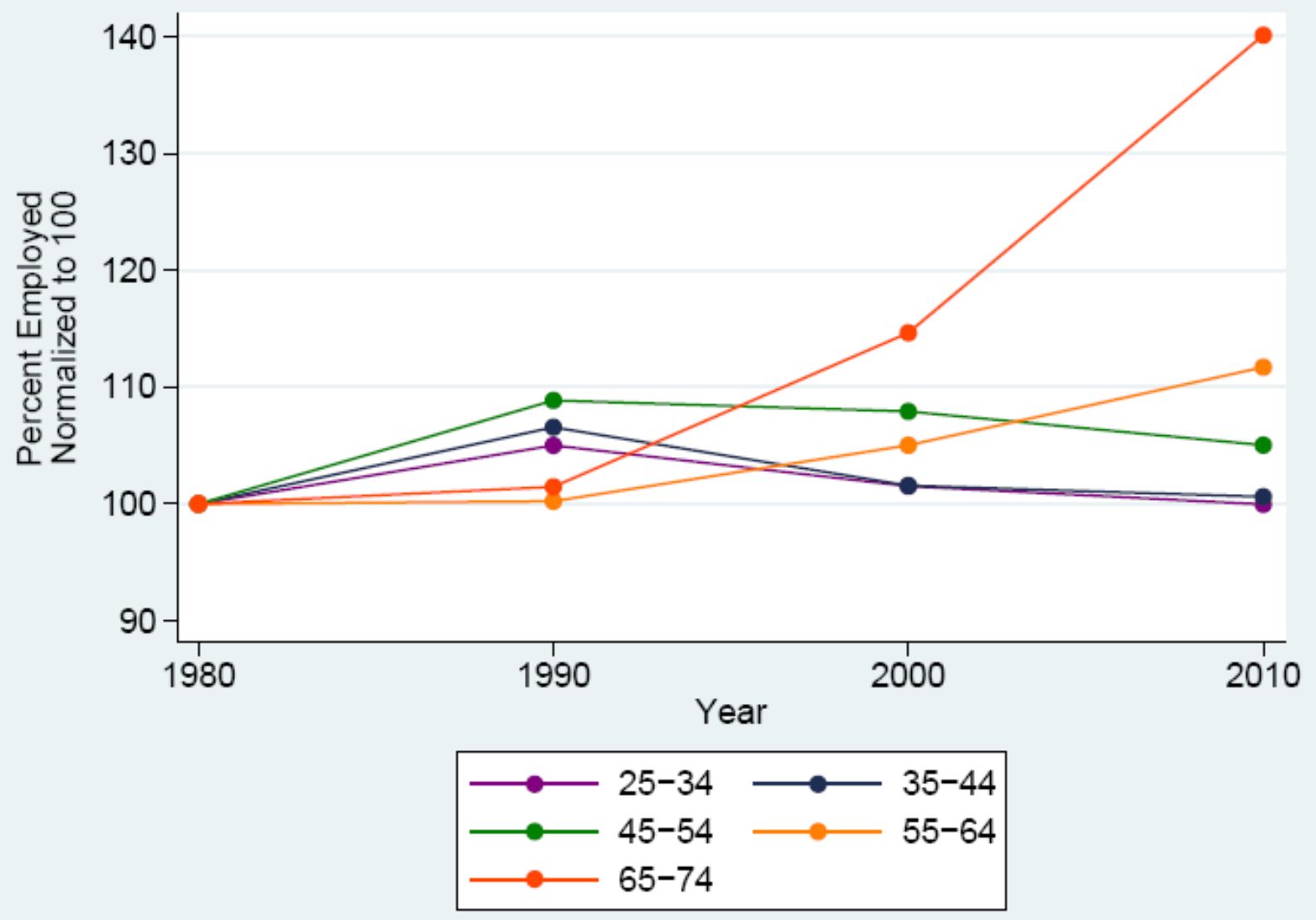


Figure 2: Employment Growth in Service Industries by Age, 1980-2010

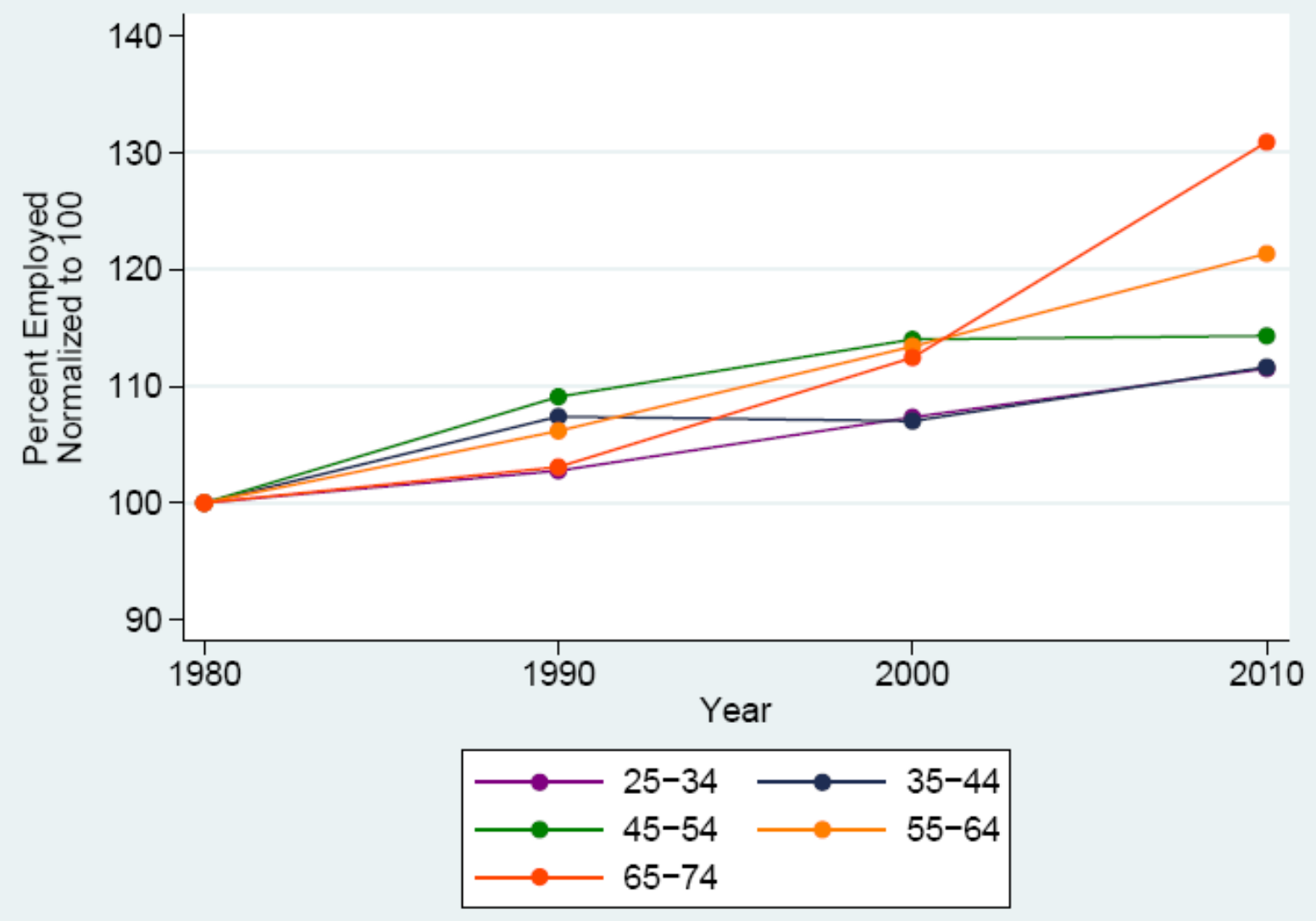


Figure 3: Employment Growth in Non-Service Industries by Age, 1980-2010

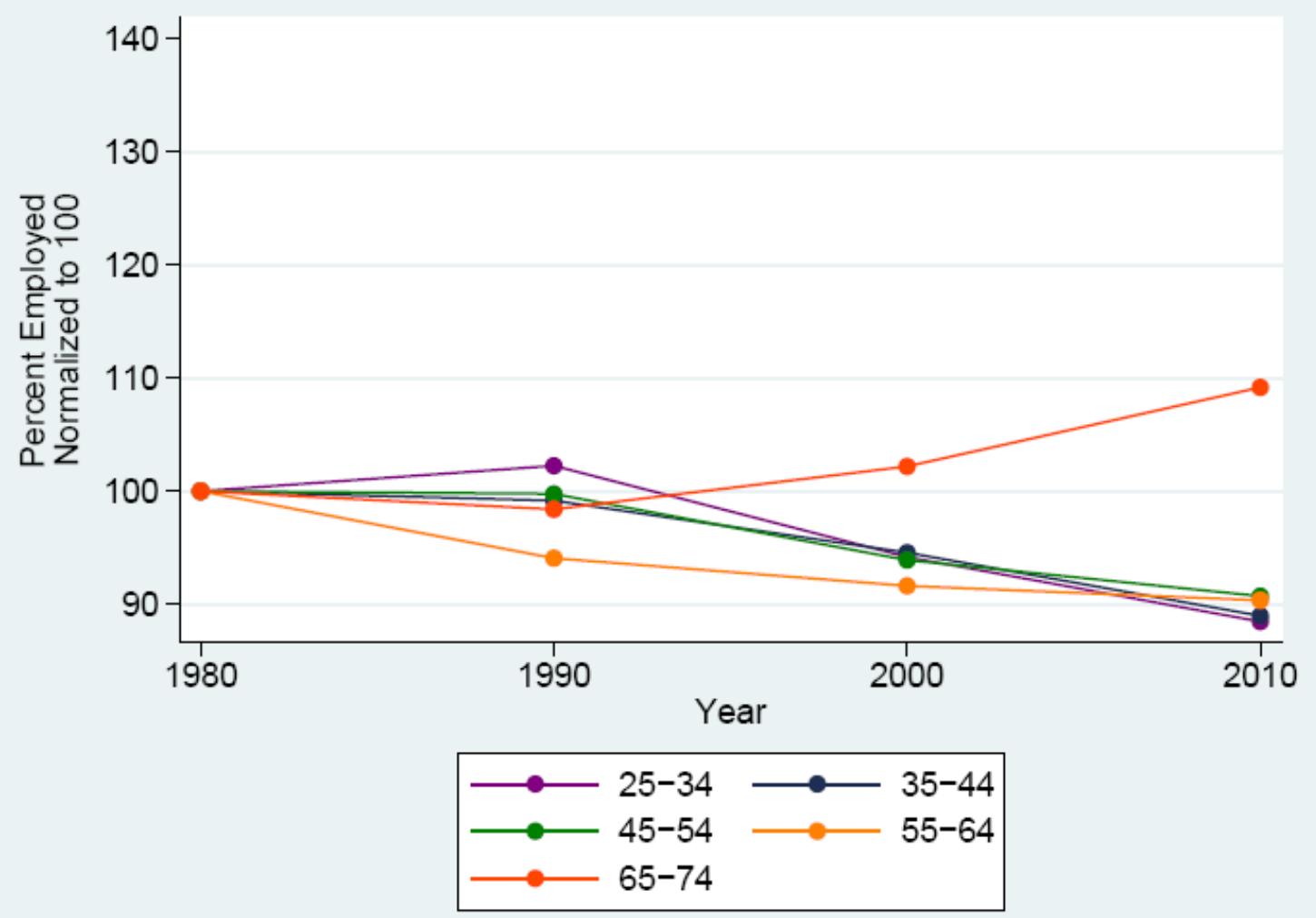


Figure 4: Employment Changes by MSA

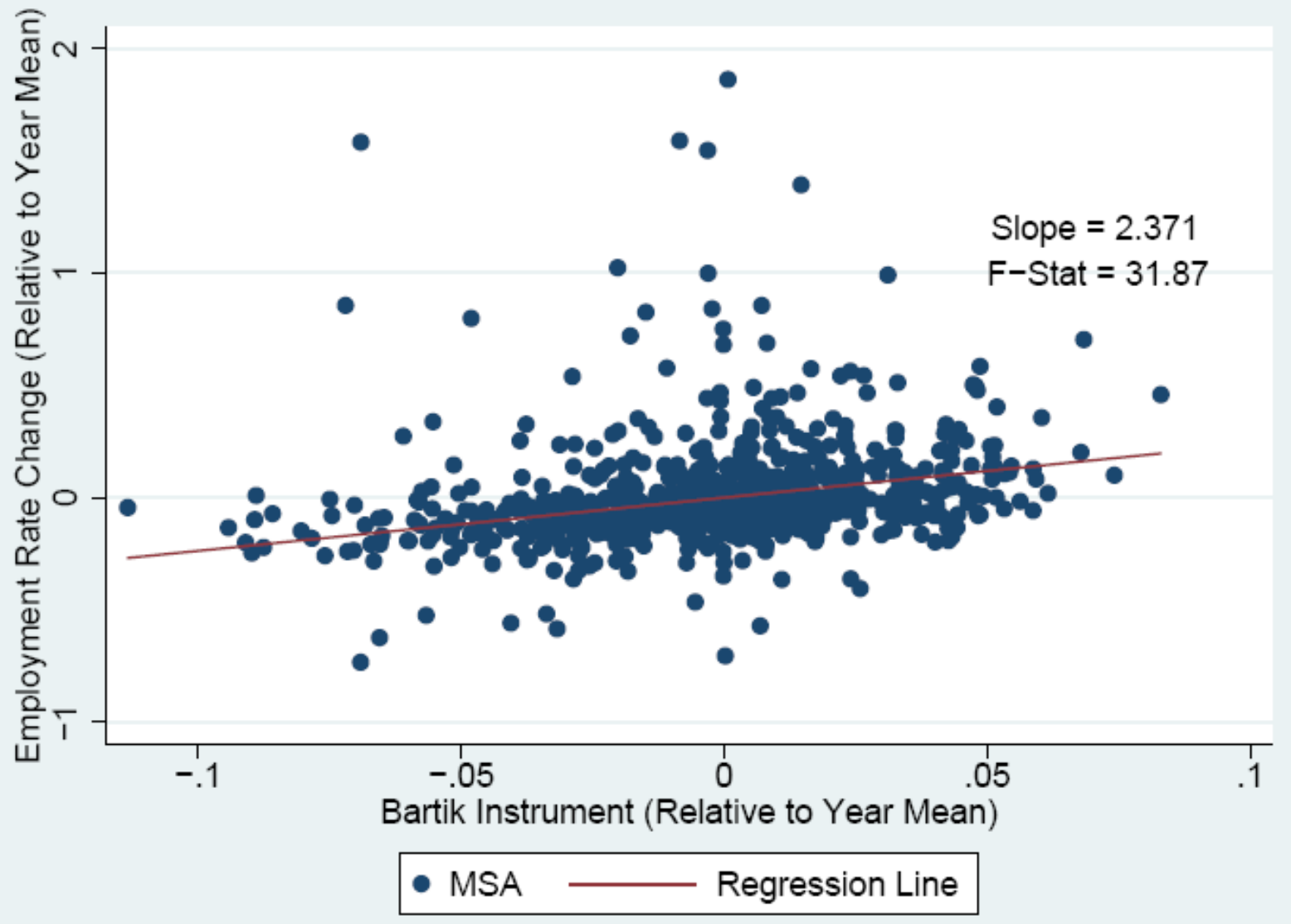


Figure 5: Effect of Employment Growth on Labor by Age

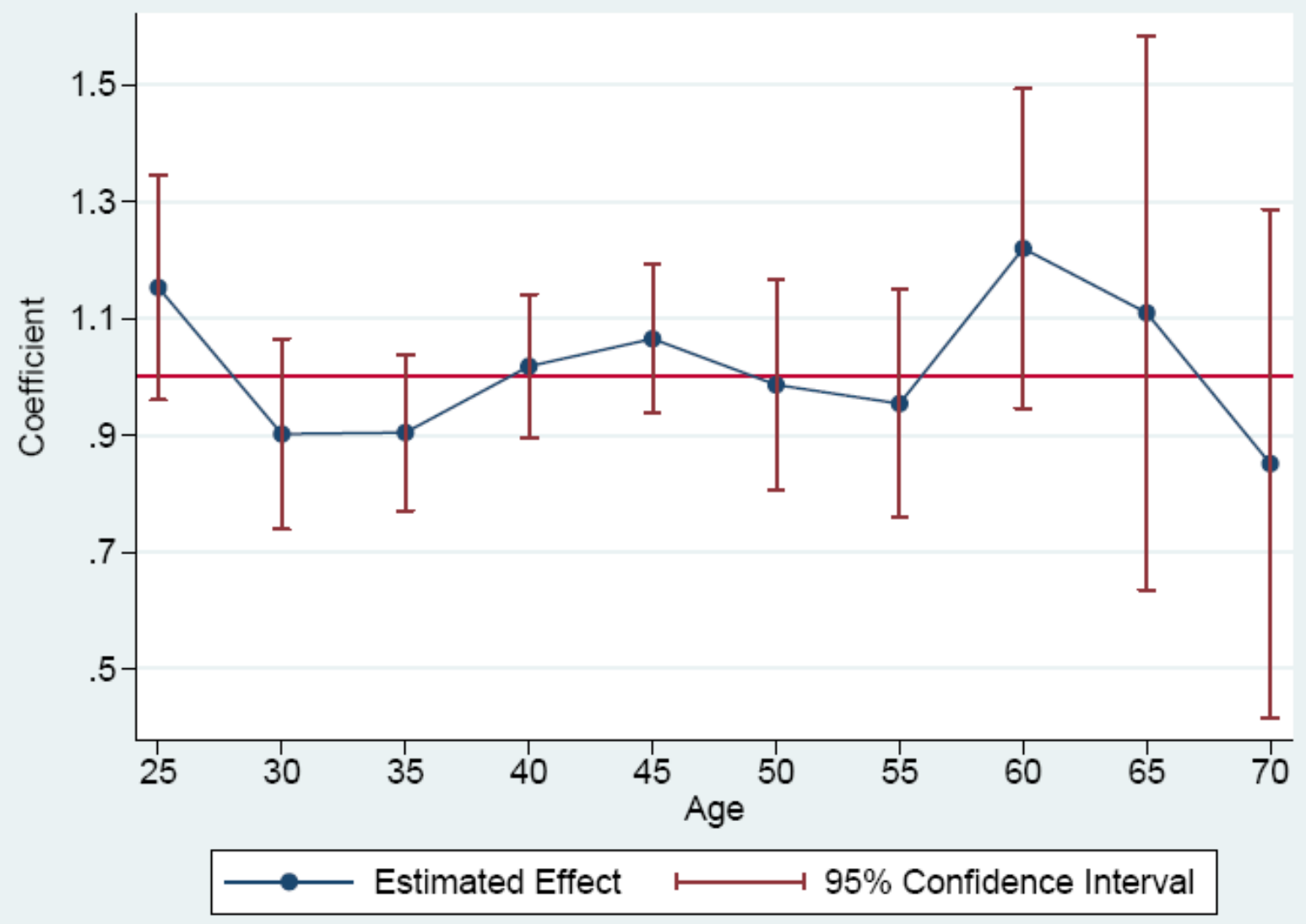


Figure 6: Effect of Employment Growth in Service Industries on Labor by Age

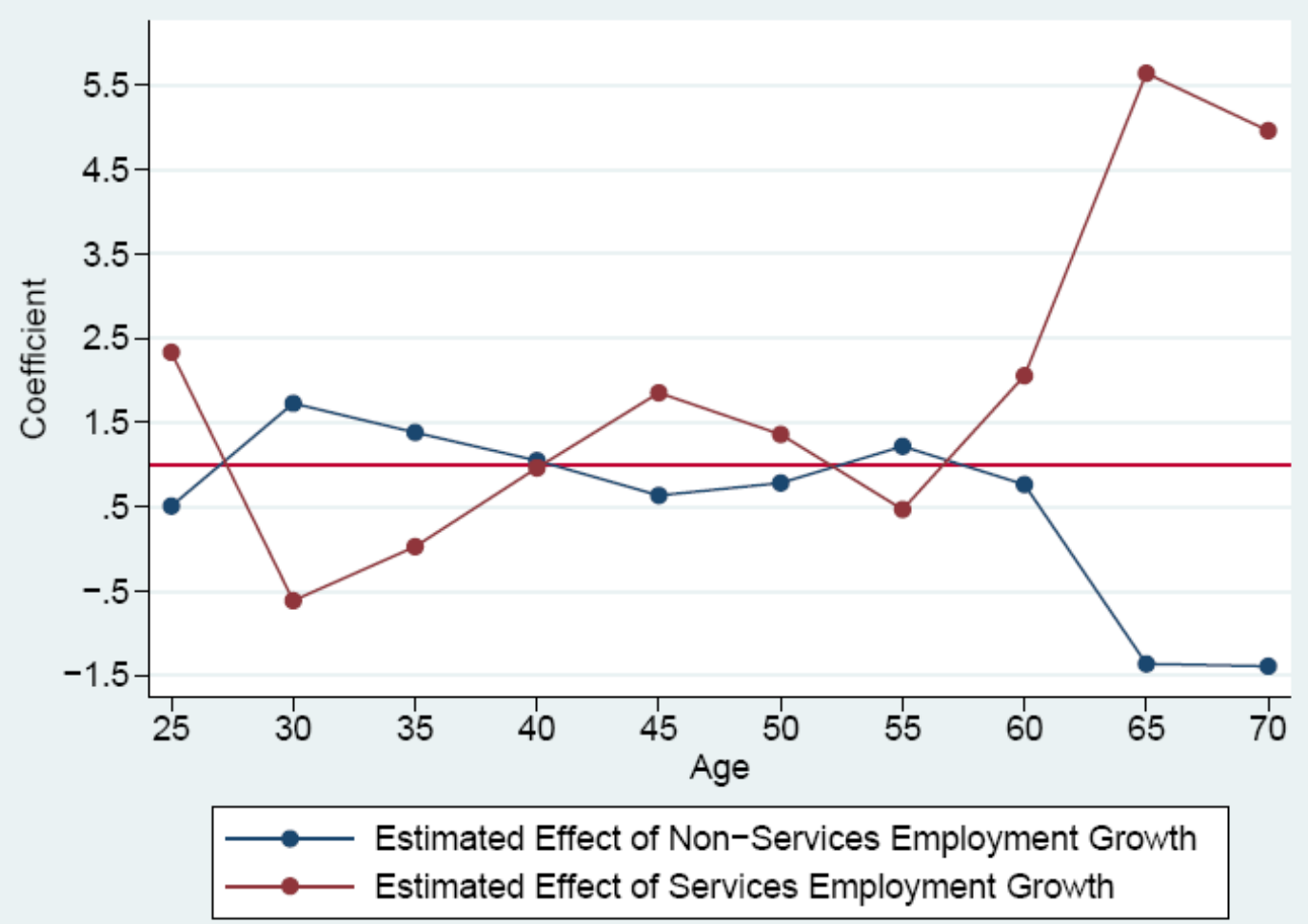




\section{Tables}

Table 1: Census and ACS Summary Statistics

\begin{tabular}{|c|c|c|c|c|c|}
\hline & 25-34 & $35-44$ & $45-54$ & $55-64$ & $65-75$ \\
\hline \multirow[t]{2}{*}{ Work } & $75.1 \%$ & $77.3 \%$ & $74.9 \%$ & $56.1 \%$ & $19.0 \%$ \\
\hline & $(43.2 \%)$ & $(41.9 \%)$ & $(43.4 \%)$ & $(49.6 \%)$ & $(39.2 \%)$ \\
\hline \multirow[t]{2}{*}{ Male } & $50.0 \%$ & $49.5 \%$ & $48.9 \%$ & $47.6 \%$ & $44.8 \%$ \\
\hline & $(50.0 \%)$ & $(50.0 \%)$ & $(50.0 \%)$ & $(49.9 \%)$ & $(49.7 \%)$ \\
\hline Less than high school & $12.8 \%$ & $13.4 \%$ & $16.3 \%$ & $22.6 \%$ & $32.2 \%$ \\
\hline High school graduate & $35.3 \%$ & $35.8 \%$ & $37.2 \%$ & $37.6 \%$ & $37.0 \%$ \\
\hline At least some college & $52.0 \%$ & $50.8 \%$ & $46.5 \%$ & $39.8 \%$ & $30.8 \%$ \\
\hline \multicolumn{6}{|l|}{ Conditional on working: } \\
\hline \multirow[t]{2}{*}{ Wage (2010 \$) } & 19.39 & 24.72 & 26.25 & 26.72 & 27.76 \\
\hline & $(45.91)$ & (100.17) & $(53.24)$ & (116.54) & (175.59) \\
\hline Agriculture & $2.5 \%$ & $2.3 \%$ & $2.4 \%$ & $2.7 \%$ & $4.6 \%$ \\
\hline Mining & $0.7 \%$ & $0.6 \%$ & $0.6 \%$ & $0.6 \%$ & $0.5 \%$ \\
\hline Construction & $7.2 \%$ & $7.3 \%$ & $6.8 \%$ & $6.0 \%$ & $5.3 \%$ \\
\hline Manufacturing & $15.8 \%$ & $16.8 \%$ & $17.1 \%$ & $17.2 \%$ & $13.9 \%$ \\
\hline Transportation & $4.0 \%$ & $4.7 \%$ & $5.1 \%$ & $5.1 \%$ & $4.2 \%$ \\
\hline Communications \& Utilities & $2.7 \%$ & $2.9 \%$ & $2.9 \%$ & $2.5 \%$ & $1.6 \%$ \\
\hline Wholesale Trade & $3.7 \%$ & $3.8 \%$ & $3.6 \%$ & $3.5 \%$ & $3.5 \%$ \\
\hline Retail Trade & $16.7 \%$ & $13.4 \%$ & $12.7 \%$ & $13.0 \%$ & $15.3 \%$ \\
\hline Finance/Insur/RealEstate & $6.6 \%$ & $6.4 \%$ & $6.3 \%$ & $6.4 \%$ & $6.6 \%$ \\
\hline Business \& Repair Services & $6.2 \%$ & $5.8 \%$ & $5.2 \%$ & $4.6 \%$ & $4.9 \%$ \\
\hline Personal Services & $3.3 \%$ & $3.2 \%$ & $3.2 \%$ & $3.5 \%$ & $4.7 \%$ \\
\hline Entertainment/Recreation & $1.4 \%$ & $1.2 \%$ & $1.1 \%$ & $1.1 \%$ & $1.6 \%$ \\
\hline Professional and Other Services & $23.5 \%$ & $25.4 \%$ & $26.8 \%$ & $27.6 \%$ & $27.5 \%$ \\
\hline Public Adminstration & $5.9 \%$ & $6.3 \%$ & $6.3 \%$ & $6.2 \%$ & $5.7 \%$ \\
\hline $\mathrm{N}$ & $6,886,968$ & $6,540,358$ & $5,710,995$ & $4,700,251$ & $3,505,573$ \\
\hline
\end{tabular}


Table 2: National Industry-Level Employment Growth Rate

\begin{tabular}{lcc|cc|cc}
\hline \hline & \multicolumn{2}{c|}{$1980-1990$} & \multicolumn{2}{c|}{$1990-2000$} & \multicolumn{2}{c}{$2000-2010$} \\
& All & MSA Sample & All & MSA Sample & All & MSA Sample \\
\hline Agriculture & 0.131 & 0.449 & -0.097 & 0.114 & 0.211 & 0.413 \\
Mining & -0.182 & -0.072 & -0.306 & -0.291 & 0.412 & 0.492 \\
Construction & 0.373 & 0.427 & 0.229 & 0.319 & 0.063 & 0.086 \\
Manufacturing & 0.014 & -0.009 & -0.044 & 0.016 & -0.183 & -0.164 \\
Transportation & 0.241 & 0.232 & 0.173 & 0.243 & 0.036 & 0.042 \\
Communications \& Utilities & 0.181 & 0.205 & 0.111 & 0.199 & 0.010 & -0.003 \\
Wholesale Trade & 0.300 & 0.321 & -0.056 & -0.014 & -0.116 & -0.113 \\
Retail Trade & 0.333 & 0.343 & 0.138 & 0.224 & 0.173 & 0.195 \\
Finance/Insurance/Real Estate & 0.481 & 0.488 & 0.097 & 0.153 & 0.108 & 0.105 \\
Business \& Repair Services & 0.763 & 0.767 & 0.447 & 0.546 & 0.161 & 0.161 \\
Personal Services & 0.230 & 0.279 & 0.129 & 0.227 & 0.233 & 0.276 \\
Entertainment/Recreation & 0.759 & 0.766 & 0.209 & 0.199 & 0.178 & 0.199 \\
Professional Services & 0.413 & 0.425 & 0.262 & 0.349 & 0.243 & 0.256 \\
Public Administration & 0.368 & 0.329 & 0.071 & 0.125 & 0.122 & 0.122 \\
\hline National & 0.269 & 0.287 & 0.132 & 0.214 & 0.102 & 0.120 \\
\hline
\end{tabular}

Source: 1980, 1990, 2000 Census, and 2009-2011 ACS.

Table 3: Employment Shares by Industry

\begin{tabular}{ccc|cc|cc}
\hline \hline & \multicolumn{2}{c}{1980} & \multicolumn{2}{c}{1990} & \multicolumn{2}{c}{2000} \\
\cline { 2 - 7 } & All & MSA Sample & All & MSA Sample & All & MSA Sample \\
\hline Agriculture & 0.029 & 0.014 & 0.026 & 0.015 & 0.021 & 0.014 \\
Mining & 0.011 & 0.006 & 0.007 & 0.004 & 0.004 & 0.002 \\
Construction & 0.059 & 0.055 & 0.063 & 0.061 & 0.069 & 0.066 \\
Manufacturing & 0.231 & 0.226 & 0.185 & 0.174 & 0.156 & 0.146 \\
Transportation & 0.048 & 0.051 & 0.047 & 0.049 & 0.049 & 0.050 \\
Communications \& Utilities & 0.031 & 0.032 & 0.029 & 0.030 & 0.028 & 0.029 \\
Wholesale Trade & 0.044 & 0.047 & 0.045 & 0.048 & 0.037 & 0.039 \\
Retail Trade & 0.127 & 0.127 & 0.133 & 0.133 & 0.134 & 0.134 \\
Finance/Insur/RealEstate & 0.060 & 0.069 & 0.071 & 0.079 & 0.068 & 0.075 \\
Business \& Repair Services & 0.034 & 0.038 & 0.048 & 0.053 & 0.061 & 0.067 \\
Personal Services & 0.031 & 0.031 & 0.030 & 0.030 & 0.030 & 0.031 \\
Entertainment/Recreation & 0.008 & 0.010 & 0.013 & 0.013 & 0.013 & 0.013 \\
Professional Services & 0.218 & 0.224 & 0.243 & 0.248 & 0.271 & 0.275 \\
Public Administration & 0.058 & 0.061 & 0.062 & 0.063 & 0.059 & 0.058 \\
\hline \hline
\end{tabular}

Source: 1980, 1990, and 2000 Census. 
Table 4: Bartik Instrument

\begin{tabular}{ccccc}
\hline \hline & Mean & Std Dev & Min & Max \\
All & 0.198 & 0.076 & 0.026 & 0.385 \\
$1980-1990$ & 0.302 & 0.032 & 0.189 & 0.385 \\
$1990-2000$ & 0.215 & 0.014 & 0.146 & 0.266 \\
$2000-2010$ & 0.120 & 0.020 & 0.026 & 0.179 \\
\hline \hline
\end{tabular}

Source: 1980, 1990, 2000 Census, and 2009-2011 ACS.

Table 5: Impact of Predicted Labor Demand Shocks on Employment and Wage Growth

\begin{tabular}{|c|c|c|c|c|c|c|c|c|c|c|}
\hline & \multicolumn{2}{|c|}{ Ages 25-34 } & \multicolumn{2}{|c|}{ Ages 35-44 } & \multicolumn{2}{|c|}{ Ages 45-54 } & \multicolumn{2}{|c|}{ Ages 55-64 } & \multicolumn{2}{|c|}{ Ages $65-74$} \\
\hline & $\begin{array}{c}\text { Employment } \\
\text { Growth }\end{array}$ & $\begin{array}{l}\text { Wage } \\
\text { Growth }\end{array}$ & $\begin{array}{c}\text { Employment } \\
\text { Growth }\end{array}$ & $\begin{array}{l}\text { Wage } \\
\text { Growth }\end{array}$ & $\begin{array}{c}\text { Employment } \\
\text { Growth }\end{array}$ & $\begin{array}{l}\text { Wage } \\
\text { Growth }\end{array}$ & $\begin{array}{c}\text { Employment } \\
\text { Growth }\end{array}$ & $\begin{array}{l}\text { Wage } \\
\text { Growth }\end{array}$ & $\begin{array}{l}\text { Employment } \\
\text { Growth }\end{array}$ & $\begin{array}{l}\text { Wage } \\
\text { Growth }\end{array}$ \\
\hline Bartik Instrument & $\begin{array}{c}2.434 * * * \\
(0.357)\end{array}$ & $\begin{array}{c}0.926 * * * \\
(0.158)\end{array}$ & $\begin{array}{c}2.248 * * * \\
(0.458)\end{array}$ & $\begin{array}{c}0.647^{* * *} \\
(0.143)\end{array}$ & $\begin{array}{c}2.455^{* * *} \\
(0.537)\end{array}$ & $\begin{array}{c}0.545^{* * *} \\
(0.149)\end{array}$ & $\begin{array}{c}2.474 * * * \\
(0.562)\end{array}$ & $\begin{array}{c}0.545^{* * *} \\
(0.137)\end{array}$ & $\begin{array}{c}2.510 * * * \\
(0.739)\end{array}$ & $\begin{array}{c}0.567^{* * *} \\
(0.148)\end{array}$ \\
\hline
\end{tabular}

***1\% Significance, $* * 5 \%$ Significance, ${ }^{*} 10 \%$ Significance. Year Fixed Effects included in all regressions. Standard errors in parentheses adjusted for clustering at MSA level.

Table 6: Description of Job Characteristic Variables in HRS

\begin{tabular}{rcr}
\hline \hline Outcome Variable & Question & Years \\
\hline Job Requirements & My job requires lots of physical effort. & $1996-2008$ \\
Physical Effort & My job requires lifting heavy loads. & $1996-2008$ \\
Heavy & My job requires stooping, kneeling, or crouching. & $1996-2008$ \\
Eyesight & My job requires good eyesight. & $1996-2008$ \\
Concentration & My job requires intense concentration or attention. & $1996-2008$ \\
People & My job requires skill in dealing with other people. & $1996-2008$ \\
Employer Policy & & $1992-2008$ \\
Reduce Hours & Could you reduce the number of hours in your regular work schedule? \\
Enjoy Work & I really enjoy going to work. \\
Psychosocial Responses & & $1996-2008$ \\
Stress & My job involves a lot of stress. & $1996-2008$ \\
Accommodate & My employer would let older workers move to a less demanding job with less pay if they wanted to. & $1996-2008$ \\
\hline \hline
\end{tabular}

For Reduce Hours, respondents answer Yes or No. Respondents are asked if they strongly agree, agree, disagree, or strongly disagree with the statement for Enjoy Work, Stress, and Accommodate. For all other variables, the respondents are asked to answer "all of almost all of the time," "most of the time," "some of the time," or "none or almost none of the time." Variables with more than 2 possible responses are divided into 2 categories (Agree or Strongly Agree vs. Disagree or Strongly Disagree; At least most of the time vs. Some of the time or less). 
Table 7: Differences in Job Characteristics - Services Industries vs. All Other Industries

\begin{tabular}{|c|c|c|c|c|}
\hline & Services & Other Industries & Difference & P-Value \\
\hline \multicolumn{5}{|l|}{ Job Requirements } \\
\hline Physical Effort & 0.279 & 0.343 & $-0.064 * * *$ & 0.000 \\
\hline Heavy & 0.101 & 0.164 & $-0.063 * * *$ & 0.000 \\
\hline Stooping & 0.223 & 0.263 & $-0.040 * * *$ & 0.000 \\
\hline Eyesight & 0.881 & 0.890 & -0.009 & 0.127 \\
\hline Concentration & 0.831 & 0.817 & $0.014 * * *$ & 0.002 \\
\hline People & 0.909 & 0.843 & $0.066^{* * *}$ & 0.000 \\
\hline \multicolumn{5}{|l|}{ Employer Policy } \\
\hline Reduce Hours & 0.359 & 0.323 & $0.036 * * *$ & 0.000 \\
\hline Accommodate & 0.347 & 0.371 & $-0.024 * * *$ & 0.000 \\
\hline \multicolumn{5}{|l|}{ Psychosocial Responses } \\
\hline Enjoy Work & 0.918 & 0.866 & $0.052 * * *$ & 0.000 \\
\hline Stress & 0.589 & 0.566 & $0.023 * * *$ & 0.000 \\
\hline
\end{tabular}


Table 8: Instrumental Variable Estimates of Impact of MSA Employment Growth on Age-Specific Employment Growth

\begin{tabular}{|c|c|c|c|c|c|c|c|c|c|c|c|c|c|c|c|}
\hline \multirow[b]{2}{*}{ Employment Growth } & \multicolumn{3}{|c|}{ Ages 25-34 } & \multicolumn{3}{|c|}{ Ages 35-44 } & \multicolumn{3}{|c|}{ Ages 45-54 } & \multicolumn{3}{|c|}{ Ages 55-64 } & \multicolumn{3}{|c|}{ Ages 65-74 } \\
\hline & $\begin{array}{c}1.027^{* * *} \\
(0.082)\end{array}$ & $\begin{array}{c}1.117^{* * *} \\
(0.472)\end{array}$ & $\begin{array}{c}1.517^{* * * *} \\
(0.481)\end{array}$ & $\begin{array}{c}0.948^{* * * *} \\
(0.054)\end{array}$ & $\begin{array}{c}1.225^{* * *} \\
(0.345)\end{array}$ & $\begin{array}{c}0.708^{* * *} \\
(0.135)\end{array}$ & $\begin{array}{c}1.035 * * * \\
(0.071)\end{array}$ & $\begin{array}{c}0.717 \\
(0.441)\end{array}$ & $\begin{array}{l}0.711^{*} \\
(0.403)\end{array}$ & $\begin{array}{c}1.043^{* * *} \\
(0.102)\end{array}$ & $\begin{array}{l}1.077^{*} \\
(0.620)\end{array}$ & $\begin{array}{l}1.025^{*} \\
(0.526)\end{array}$ & $\begin{array}{c}1.059 * * * \\
(0.226)\end{array}$ & $\begin{array}{l}-1.488 \\
(0.944)\end{array}$ & $\begin{array}{l}1.590^{*} \\
(0.861)\end{array}$ \\
\hline Employment Growth (Services) & & $\begin{array}{c}0.871 \\
(1.041)\end{array}$ & & & $\begin{array}{c}0.441 \\
(0.691)\end{array}$ & & & $\begin{array}{l}1.620^{*} \\
(0.963)\end{array}$ & & & $\begin{array}{c}0.982 \\
(1.334)\end{array}$ & & & $\begin{array}{c}5.730 * * * \\
(2.076)\end{array}$ & \\
\hline Employment Growth (Retail Trade) & & & $\begin{array}{l}-3.125 \\
(3.270)\end{array}$ & & & $\begin{array}{c}2.978 * * * \\
(0.932)\end{array}$ & & & $\begin{array}{c}3.785 \\
(2.790)\end{array}$ & & & $\begin{array}{c}1.200 \\
(3.648)\end{array}$ & & & $\begin{array}{l}-3.438 \\
(5.763)\end{array}$ \\
\hline
\end{tabular}

***1\% Significance, ${ }^{* * 5 \%}$ Significance, ${ }^{*} 10 \%$ Significance. Year Fixed Effects included in all regressions. Standard errors in parentheses adjusted for clustering at MSA level. 
Table 9: Bartik Instrument in the HRS

\begin{tabular}{ccccc}
\hline \hline & Mean & Std Dev & Min & Max \\
All & 0.025 & 0.026 & -0.078 & 0.063 \\
$1992-1994$ & 0.048 & 0.006 & 0.029 & 0.061 \\
$1994-1996$ & 0.048 & 0.005 & 0.03 & 0.061 \\
$1996-1998$ & 0.052 & 0.006 & 0.031 & 0.063 \\
$1998-2000$ & 0.044 & 0.008 & 0.013 & 0.062 \\
$2000-2002$ & -0.018 & 0.013 & -0.078 & 0.009 \\
$2002-2004$ & 0.006 & 0.007 & -0.022 & 0.024 \\
$2004-2006$ & 0.034 & 0.005 & 0.015 & 0.045 \\
$2006-2008$ & 0.004 & 0.006 & -0.024 & 0.016 \\
\hline
\end{tabular}

Table 10: Marginal Effects of Predicted Labor Demand Shocks

\begin{tabular}{|c|c|c|c|c|}
\hline & \multicolumn{4}{|c|}{ All } \\
\hline & $\mathrm{P}$ ( Work at $\mathrm{t} \mid$ Work at $\mathrm{t}-\mathrm{1})$ & P( Work at $\mathrm{t} \mid$ Not Work at $\mathrm{t}-1)$ & $\mathrm{P}($ Retired at $\mathrm{t} \mid$ Not Retired at $\mathrm{t}-1)$ & $\mathrm{P}$ ( Retired at $\mathrm{t} \mid$ Retired at $\mathrm{t}-\mathrm{1})$ \\
\hline \multirow[t]{2}{*}{ Bartik Instrument } & $0.0074^{* *}$ & $0.0062^{* *}$ & $-0.0056^{* *}$ & 0.0019 \\
\hline & $(0.0037)$ & $(0.0025)$ & $(0.0024)$ & $(0.0054)$ \\
\hline $\mathrm{N}$ & 40252 & 37686 & 51340 & 26598 \\
\hline \multirow[t]{3}{*}{ Mean of Outcome } & 0.8300 & 0.0889 & 0.1664 & 0.8439 \\
\hline & \multicolumn{4}{|c|}{ Men } \\
\hline & $\mathrm{P}$ ( Work at $\mathrm{t} \mid \mathrm{Work}$ at $\mathrm{t}-\mathrm{1})$ & P( Work at $\mathrm{t} \mid$ Not Work at $\mathrm{t}-\mathrm{1})$ & $\mathrm{P}($ Retired at $\mathrm{t} \mid$ Not Retired at $\mathrm{t}-1)$ & $\mathrm{P}($ Retired at $\mathrm{t} \mid$ Retired at $\mathrm{t}-\mathrm{1})$ \\
\hline \multirow[t]{2}{*}{ Bartik Instrument } & 0.0041 & 0.0040 & $-0.0069^{*}$ & 0.0032 \\
\hline & $(0.0042)$ & $(0.0040)$ & $(0.0040)$ & $(0.0061)$ \\
\hline $\mathrm{N}$ & 20432 & 14138 & 22320 & 12250 \\
\hline \multirow[t]{3}{*}{ Mean of Outcome } & 0.8424 & 0.1044 & 0.1571 & 0.8778 \\
\hline & \multicolumn{4}{|c|}{ Women } \\
\hline & P( Work at $\mathrm{t} \mid \mathrm{W}$ Work at $\mathrm{t}-1)$ & P( Work at $\mathrm{t} \mid$ Not Work at t-1) & $\mathrm{P}($ Retired at $\mathrm{t} \mid$ Not Retired at $\mathrm{t}-1)$ & $\mathrm{P}($ Retired at $\mathrm{t} \mid$ Retired at $\mathrm{t}-\mathrm{1})$ \\
\hline \multirow[t]{2}{*}{ Bartik Instrument } & $0.0112^{* *}$ & $0.0079^{* * *}$ & $-0.0044^{*}$ & 0.0011 \\
\hline & $(0.0047)$ & $(0.0031)$ & $(0.0025)$ & $(0.0063)$ \\
\hline $\mathrm{N}$ & 19820 & 23548 & 29020 & 14348 \\
\hline \multirow[t]{3}{*}{ Mean of Outcome } & 0.8160 & 0.0790 & 0.1744 & 0.8134 \\
\hline & \multicolumn{4}{|c|}{ Low Education } \\
\hline & P( Work at $\mathrm{t}$ | Work at $\mathrm{t}-1)$ & P( Work at $\mathrm{t} \mid$ Not Work at t-1) & $\mathrm{P}($ Retired at $\mathrm{t}$ | Not Retired at $\mathrm{t}-1)$ & $\mathrm{P}($ Retired at $\mathrm{t} \mid$ Retired at $\mathrm{t}-1)$ \\
\hline \multirow[t]{2}{*}{ Bartik Instrument } & 0.0013 & 0.0025 & -0.0012 & 0.0062 \\
\hline & $(0.0060)$ & $(0.0026)$ & $(0.0045)$ & $(0.0061)$ \\
\hline $\mathrm{N}$ & 21267 & 25673 & 29822 & 17118 \\
\hline \multirow[t]{3}{*}{ Mean of Outcome } & 0.8006 & 0.0766 & 0.1932 & 0.8381 \\
\hline & \multicolumn{4}{|c|}{$\begin{array}{ll} & \text { High Education } \\
\end{array}$} \\
\hline & P( Work at $\mathrm{t}$ | Work at t-1) & $\mathrm{P}(\mathrm{W}$ ork at $\mathrm{t} \mid$ Not Work at $\mathrm{t}-1)$ & $\mathrm{P}($ Retired at $\mathrm{t}$ | Not Retired at $\mathrm{t}-1)$ & $\mathrm{P}($ Retired at $\mathrm{t} \mid$ Retired at $\mathrm{t}-\mathrm{1})$ \\
\hline \multirow[t]{2}{*}{ Bartik Instrument } & 0.0074 & $0.0096^{*}$ & -0.0053 & -0.0110 \\
\hline & $(0.0050)$ & $(0.0058)$ & $(0.0046)$ & $(0.0080)$ \\
\hline $\mathrm{N}$ & 18985 & 12013 & 21518 & 9480 \\
\hline Mean of Outcome & 0.8561 & 0.1120 & 0.1372 & 0.8543 \\
\hline
\end{tabular}


Table 11: Marginal Effects of Predicted Labor Demand Shocks (Service Industries vs. Non-Service Industries)

\begin{tabular}{|c|c|c|c|c|}
\hline & P( Work at $\mathrm{t}$ | Work at $\mathrm{t}-1)$ & $\mathrm{P}(\mathrm{W}$ ork at $\mathrm{t}$ | Work at $\mathrm{t}-1)$ & P( Work at $\mathrm{t} \mid$ Not Work at t-1) & $\mathrm{P}($ Work at $\mathrm{t}$ | Not Work at t-1) \\
\hline \multirow[t]{2}{*}{ Bartik Instrument } & $0.0074^{* *}$ & & $0.0062^{* *}$ & \\
\hline & $(0.0037)$ & & $(0.0025)$ & \\
\hline \multirow[t]{2}{*}{ Bartik Instrument (Excluding Services) } & & 0.0048 & & $0.0069 *$ \\
\hline & & $(0.0043)$ & & $(0.0036)$ \\
\hline \multirow[t]{2}{*}{ Bartik Instrument (Services) } & & $0.0107^{* *}$ & & 0.0059 \\
\hline & & $(0.0054)$ & & $(0.0037)$ \\
\hline $\mathrm{N}$ & 40008 & 40008 & 36419 & 36419 \\
\hline Mean of Outcome & 0.8306 & 0.8306 & 0.0902 & 0.0902 \\
\hline $\begin{array}{l}* * * 1 \% \text { Significance, } * * 5 \% \text { Significance, } \\
\text { of an increase in the Bartik Instrum } \\
\text { instrument by } 0.01 \text { one at a time and re }\end{array}$ & $\begin{array}{l}10 \% \text { Significance. Age, Year } \\
\text { hent by } 0.01 \text { for the entire sa } \\
\text { port the resulting marginal }\end{array}$ & $\begin{array}{l}\text { ind Sex Fixed Effects include } \\
\text { ple. Probit regressions estir } \\
\text { fects. Standard errors in par }\end{array}$ & $\begin{array}{l}\text { all regressions. All estimates re } \\
\text { d to obtain predicted probabilit } \\
\text { eses generated from clustered ( }\end{array}$ & $\begin{array}{l}\text { s. We the mean estimated effect } \\
\text { s. Wease each Bartik } \\
\text { y Commuting Zone) bootstrap. }\end{array}$ \\
\hline
\end{tabular}

Table 12: The Effect of Predicted Labor Demand Shocks on Wages and Earnings

\begin{tabular}{|c|c|c|c|c|c|c|}
\hline & $\ln$ (wages) & In(wages) & In(wages) & Labor Earnings & Labor Earnings & Labor Earnings \\
\hline Bartik Instrument & $\begin{array}{c}0.122^{* * *} \\
(0.024)\end{array}$ & $\begin{array}{c}0.040^{* * *} \\
(0.010)\end{array}$ & $\begin{array}{c}0.111^{* * *} \\
(0.026)\end{array}$ & $\begin{array}{c}5232.61^{* * *} \\
(1428.38)\end{array}$ & $\begin{array}{c}2531.61^{* * *} \\
(716.55)\end{array}$ & $\begin{array}{c}210.14^{*} \\
(116.83)\end{array}$ \\
\hline $\mathrm{N}$ & 25,363 & 25,363 & 2,502 & 40,008 & 40,008 & 36,419 \\
\hline Control for Previous Wage (Earnings) & No & Yes & $N / A$ & No & Yes & N/A \\
\hline Worked at t-1? & Yes & Yes & No & Yes & Yes & No \\
\hline Mean Wage (Earnings) & 26.77 & 26.77 & 25.45 & 32682.9 & 32682.9 & 1244.67 \\
\hline
\end{tabular}

***1\% Significance, **5\% Significance, *10\% Significance. Age, Year, and Sex Fixed Effects included in all regressions. Labor Earnings results are reported by estimating the effect of an increase in the Bartik Instrument by 0.01 . Standard errors in parentheses generated from clustered (by Commuting Zone) bootstrap.

Table 13: The Effect of Predicted Labor Demand Shocks on Social Security Claiming Behavior

\begin{tabular}{ccccccccc}
\hline \hline \multirow{2}{*}{$\begin{array}{c}\text { Age } \\
\text { Bgartik Instrument }\end{array}$} & $\mathbf{6 2}$ & $\mathbf{6 3}$ & $\mathbf{6 4}$ & $\mathbf{6 5}$ & $\mathbf{6 6}$ & $\mathbf{6 7}$ & $\mathbf{6 8}$ & $\mathbf{6 9}$ \\
\cline { 2 - 9 } & $-0.067^{* * *}$ & $-0.035^{*}$ & $-0.040^{* *}$ & 0.004 & -0.016 & 0.023 & $-0.060^{*}$ & -0.013 \\
$\mathrm{~N}$ & $(0.016)$ & $(0.020)$ & $(0.018)$ & $(0.022)$ & $(0.016)$ & $(0.033)$ & $(0.035)$ & $(0.024)$ \\
Mean Outcome & 0,068 & 3,623 & 1,919 & 1,425 & 962 & 474 & 267 & 226 \\
\hline \hline
\end{tabular}

***1\% Significance, $* * 5 \%$ Significance, *10\% Significance. Age, Year, and Sex Fixed Effects included

in all regressions. All estimates refer to the mean estimated effect of an increase in the Bartik Instrument by 0.01 for the entire sample. Standard errors in parentheses generated from clustered (by Commuting Zone) bootstrap. 
Table 14: The Effect of Predicted Labor Demand Shocks on Job Characteristics

\begin{tabular}{|c|c|c|c|c|c|c|c|c|c|c|}
\hline \multirow[b]{2}{*}{ Bartik Instrument } & \multicolumn{2}{|c|}{ Reduce Hours } & \multicolumn{2}{|c|}{ Enjoy Work } & \multicolumn{2}{|c|}{ Physical Effort } & \multicolumn{2}{|c|}{ Heavy } & \multicolumn{2}{|c|}{ Stoop } \\
\hline & $0.012^{*}$ & -0.013 & -0.003 & $-0.017 *$ & $-0.024 * * *$ & -0.019 & $-0.014 * * *$ & -0.006 & $-0.020 * * *$ & $-0.027^{* *}$ \\
\hline & (0.007) & $(0.020)$ & $(0.004)$ & (0.009) & $(0.008)$ & $(0.015)$ & $(0.005)$ & $(0.010)$ & $(0.007)$ & $(0.013)$ \\
\hline Worked at t-1? & Yes & No & Yes & No & Yes & No & Yes & No & Yes & No \\
\hline $\mathrm{N}$ & 23722 & 1880 & 21809 & 2358 & 5709 & 2306 & 5656 & 2297 & 5687 & 2298 \\
\hline \multirow[t]{2}{*}{ Mean Dep Var } & 0.353 & 0.501 & 0.894 & 0.927 & 0.310 & 0.360 & 0.136 & 0.128 & 0.245 & 0.252 \\
\hline & \multicolumn{2}{|c|}{ Eyesight } & \multicolumn{2}{|c|}{ Concentration } & \multicolumn{2}{|c|}{ People } & \multicolumn{2}{|c|}{ Stress } & \multicolumn{2}{|c|}{ Accommodate } \\
\hline \multirow[t]{2}{*}{ Bartik Instrument } & -0.001 & -0.003 & 0.009 & -0.006 & 0.004 & $0.027^{*}$ & $-0.007^{*}$ & 0.014 & -0.005 & $-0.038^{*}$ \\
\hline & $(0.005)$ & (0.009) & $(0.008)$ & $(0.017)$ & (0.005) & $(0.015)$ & $(0.004)$ & $(0.016)$ & $(0.006)$ & $(0.021)$ \\
\hline Worked at t-1? & Yes & No & Yes & No & Yes & No & Yes & No & Yes & No \\
\hline $\mathrm{N}$ & 5738 & 2308 & 5745 & 2309 & 5743 & 2308 & 21840 & 2366 & 14911 & 1493 \\
\hline Mean Dep Var & 0.896 & 0.846 & 0.812 & 0.737 & 0.868 & 0.810 & 0.561 & 0.354 & 0.366 & 0.362 \\
\hline
\end{tabular}

$* * * 1 \%$ Significance, $* * 5 \%$ Significance, $* 10 \%$ Significance. Age, Year, and Sex Fixed Effects included in all regressions. In regressions for the sample that worked at time $t-1$, the value of the outcome variable at time $t-1$ is also included. All estimates refer to the mean estimated effect of an increase in the Bartik Instrument from 0 to 0.01 for the entire sample. Standard errors in parentheses generated from clustered (by Commuting Zone) bootstrap.

Table 15: The Effect of Negative Industry-Specific Labor Demand Shocks

\begin{tabular}{ccccccc}
\hline \hline \multirow{3}{*}{ All } & FT Work & \multicolumn{2}{c}{ Any Work PT or FT Ret } & FT Ret & Change Industry & In(Wage) \\
\cline { 2 - 7 } & -0.025 & $-0.033^{* * *}$ & $0.030^{*}$ & $0.030^{* * *}$ & -0.009 & 0.024 \\
& $(0.016)$ & $(0.013)$ & $(0.016)$ & $(0.011)$ & $(0.007)$ & $(0.027)$ \\
Men & $-0.035^{* *}$ & -0.023 & 0.017 & 0.024 & $-0.020^{* *}$ & 0.048 \\
& $(0.017)$ & $(0.021)$ & $(0.022)$ & $(0.021)$ & $(0.009)$ & $(0.036)$ \\
Women & 0.001 & -0.051 & $0.058^{* *}$ & $0.043^{* *}$ & 0.006 & -0.029 \\
& $(0.037)$ & $(0.034)$ & $(0.027)$ & $(0.018)$ & $(0.007)$ & $(0.047)$ \\
Low Ed & -0.025 & $-0.033^{* * *}$ & $0.041^{* * *}$ & $0.045^{* * *}$ & -0.013 & 0.034 \\
& $(0.019)$ & $(0.009)$ & $(0.013)$ & $(0.010)$ & $(0.007)$ & $(0.031)$ \\
High Ed & -0.028 & -0.037 & 0.014 & 0.015 & -0.003 & 0.007 \\
& $(0.024)$ & $(0.025)$ & $(0.022)$ & $(0.016)$ & $(0.015)$ & $(0.029)$ \\
\hline \hline
\end{tabular}

$* * * 1 \%$ Significance, $* * 5 \%$ Significance, $* 10 \%$ Significance. Each cell reports the result from a separate regression. Age, Year, and Sex Fixed Effects included in all regressions. All estimates refer to the mean estimated effect of a change in the probability of the outcome due to experiencing a bad industry shock. Standard errors in parentheses generated from clustered (by industry) bootstrap. 